\title{
Conference Review
}

\section{'Studies in Cotton Nero a.x. (the Gawain-Manuscript)'}

\author{
LOMERS $10^{\text {th }}$ Annual Summer Conference, Institute of English Studies, \\ 18-19 June 2010'
}

\begin{abstract}
Sam Hall
THE NARRATOR OF PEARL, the Middle English alliterative poem whose author is known to us only as the Gawain-poet, has a dream which leaves him transformed. During the course of his vision the dreamer learns that true value cannot be ascertained by the study of external features. It becomes clear that the pearl in question, his daughter, is valuable to him not as an object, 'so rounde, so reken in uche araye' ['so beautiful in every setting'], whose external features are to be judged, but rather, as a way for him to know his maker. ${ }^{2}$ On waking in the temporal world, he laments his previously wavering faith and wishes he had listened to his daughter, rather than self-indulgently mourning: 'to that prynces paye hade I ay bente [...] as the perle me prayed' ['had I but listened to God [...] as my pearl told me to']. ${ }^{3}$ Pearl values subjectivity: the pearl maiden's function, or rather, value, is ontological rather than aesthetic. Ironically, the conference's primary aim was to evaluate the aesthetic value and interpret the external feature of the text, that is, the manuscript. However, this did not mar the proceedings, which were both scintillating and heated. Moreover, after being enlightened as to the sheer amount of effort that goes into editing these poems and how this can shape meaning, external valuation and interpretation must be a precursor to any study. I was convinced by the virtues of being a 'manuscript man', or, at least, almost.
\end{abstract}

\section{Keynote Speech}

Using mathematics, Professor Derek Pearsall sought to prove that Sir Gawain, Patience, and Cleanness were written by the same person. The method he used isolated a high degree of similarity between the recurrence of lines 'commencing with individual function words'. His results showed that each poem in the Gawain-poet's oeuvre had a similar number of syllables per line. 
Fed into a computer, these numbers produce a convincing scattergram in which the three control poems appear in the periphery, while the three poems by the Gawain-poet are closely grouped. So there we have it: they were all written by the same person, or at least, by a virtuoso imitator. However, as Professor Pearsall himself admitted, the omission of Pearl from his study casts doubt upon all of his information, potentially invalidating his thesis. This study, using the very latest technology, goes some way towards removing one uncertainty from a discipline full of uncertainties, and this, by his own admission, was all that Professor Pearsall aimed to achieve. If nothing else, such groundbreaking work succeeds in reminding us that the text is never stable. Comparisons between works in the Gawain-poet's oeuvre could potentially be less tenuous then we had previously thought. Neat identifications may finally prove to be possible, or at least almost.

\section{Lectures on Palaeography and Textual Fidelity}

Accessibility, it seems, is a watchword in the study of the Gawain-poet. The lectures given by Ad Putter and later by Murray McGillivray and Kenna Olsen were, in very different ways, concerned with the clarification of a difficult manuscript. Putter and Myra Stokes have been working on a new edition of Cleanness using the process of scribal emendation to remove a few more uncertainties from a text that is quite ambiguous enough. McGillivray and his colleagues have been developing a fully digitized, searchable, and significantly, enlargeable copy of the manuscript with parallel texts and an up-to-date bibliography. While this undertaking may be likened to painting the Forth (or perhaps Humber) Bridge, its usefulness in resolving textual infidelities or closely studying the illustrations of the text cannot be overstated. Their aim is to have a searchable version of MS Cotton Nero A.x. online by next year, creating the potential for nothing short of a revolution in the study of the Gawain-poet. Their arduous labour is as democratic in its intentions as it is commendable. The British Library is assisting in the digitization project by supplying the photographs of the manuscript. The British Library was represented by Julian Harrison, who opened the conference with a detailed lecture on the material history of the text, its numeration, re-discovery and thoughts on what insights might arise from recent innovations in palaeography. Tony Davenport provided an illuminating discussion about the illustrations of the Pearl manuscript, detecting, among other things, a similarity between the rather crudely executed picture of the dreamer by the river and that of Narcissus in Roman de la Rose. The forthcoming digitization may shed light on why the book is illustrated by an artist of, at best, quotidian skill.

\section{Readings of the Text}

Nothing, not even the text itself, is as it seems and the greatest strength of the readings presented at this conference was a recognition of this truth. Alcuin 
Blamires brilliantly argued that shame plays a pivotal role in Sir Gawain and the Green Knight. 'Collateral shame', that is, the potential for the shaming of his group, is what motivates Gawain to act. It is through the personal shame of betraying Bertilak's hospitality that Gawain learns some healthy introspection. Thus, he returns to the ostentatious displays of conspicuous consumption at Arthur's court as a changed man, ill at ease. Rosalind Field's particularly interesting paper was concerned with the way that the Gawain-poet rewrote the revelation of St John. Dr Field also identified a tradition of contemporaneous commentaries about the seven-horned and seven-eyed lamb of the apocalypse. Moreover, little research has been undertaken concerning analogues between the motherly Pearl maiden and the cult of the Virgin. This area would certainly warrant further exploration.

According to Susanna Fein, the numerous legends which link John the Evangelist with precious stones make him an obvious choice for a poem about the loss of a pearl. She examined the extensive visual and textual analogues between John's judging, giving, and receiving of Edward the Confessor's ring, and the Pearl narrator's own preoccupation with external appearance. This paper promised as much as it delivered. The same may be said in a more pejorative sense about Ian Kirby's paper 'Hautdesert Identified'. It certainly did what it said on the tin. However, one is forced to question the validity of attempting to find locations from poetry. What aid is it, to that most overreaching of aspirations: the complete understanding of a poem? Why claw after the empirical data? Such epistimania provides neither entertainment nor insight. However, since the conference's chosen focus was the manuscript, it can be admitted that the location of a poet/poem has its role to play in palaeography. Indeed, Joel Fredell's paper proved a connection between palaeography and location by arguing that the Cotton Nero A.x manuscript was written in York, or rather that the scribe was trained in or near that city.

\section{Atmosphere}

In common with all LOMERS events, there was an air of friendliness and acceptance. It drew together delegates from both sides of the Atlantic, diverse generations of academics and people who simply shared an interest in the text. Due to McGillivray's commendable digitization project, the study of MS Cotton Nero A.x. is on the cusp of a revolution, or should I say, those who study it face a revelation. It is the potential for revelation that motivated the dreamer of Pearl to face life again. While it remains to be seen what neat identifications may be elucidated from the text because of this project, they will provide the fodder for future conferences such as this and perhaps moments of revelation too.

Royal Holloway, University of London 


\section{Notes}

1. More information at $<$ http://ies.sas.ac.uk/events/conferences/2010/Lomers/index.htm $>$ [accessed 2 January 2011].

2. Sir Gawain and the Green Knight, Pearl, Cleanness, Patience, ed. by J. J. Anderson (London: Everyman, 1996), p. 5.

3. Anderson, p. 45. 